DOI: $10.21554 / h r r .091812$

\title{
STRATEGIC MANAGEMENT AND ITS IMPORTANCE IN THE BANKING SECTOR
}

\section{Snježana Stanišić ${ }^{1}$}

Sinergija University, Bosna i Hercegovina

\author{
Professional paper
}

\begin{abstract}
Management in banks has a unique aim, which is to create a clear picture of the appropriate directing of banking products, characterised by concentration on quality and integrity, maintaining interaction with the employees and beneficiaries of banking services and products, as well as creating solutions that would more successfully fulfil their needs. In order to achieve this, the management team should, first of all, accept all the accurate information on previous transactions, both those of legal and physical persons, and should fulfil their needs and realise their demands based on the principle of a business relationship. On account of the increased competition on the market, banks are additionally stimulated to introduce changes in their operations, to modernise their offer in order to survive on the market. The process of strategic planning in the banking sector may be presented as one of the most important factors for its long-term successful business operations.
\end{abstract}

Keywords: Banking services and products, competition on the market, strategic planning

\section{INTRODUCTION}

The conditions for conducting business operations in the banking sector have changed over time, as a result of which banks have adapted to the market conditions in various ways. The introduction of new technologies and the modernisation of business operations have contributed to facilitating business operations through the automatisation and acceleration of tasks. The number of banks is increasing, which has led to the increase of competition. In keeping with the new market conditions, banks have introduced a large number of new services and products, with which they could attract new clients, as well as retain the existing ones, striving to ensure better conditions through their business efficiency. Planning, organising, controlling and managing are components that are mutually interlinked and define what the management must do. Strategic planning, as a means of positioning one's bank on a competitive market and of searching for a method for strengthening the bank's position in the future, is implemented by all banks. Under the conditions of the functioning of the contemporary financial market, the essential element of bank management is strategic planning. The results that could be achieved in the coming period should be the main aim of the management. By defining concrete aims, whose realisation may be controlled and monitored, it is possible to undertake measures in a timely manner, if need be, for the purpose of improving business operations.

\footnotetext{
${ }^{1}$ Correspondence to:

Snježana Stanišić, Sinergija University, Bosnia and Herzegovina

Raje Baničića bb Bijeljina, Bosnia and Herzegovina

E-mail: sstanisic@sinergija.edu.ba
} 
Planning should be revised from time to time, including new information and circumstances. This should induce the management to follow the changes in the surrounding area, as well as inside the bank itself, which requires a lot of time and is not simple, but the results of such analyses may prove very useful. For a bank to conduct its business operations successfully, the management needs specific and universal knowledge and abilities. To prepare, pass, realise and analyse a decision if the responsibility of the management in banking, which is represented by an individual or a team. Apart from quality and ability, the banking management must possess leadership-related knowledge, ability and quality. The management of as bank is made up of managers who are at all the levels of the organisational and managerial structure, and it consists of the operative, middle and top-level management. The process through which managers define the mission of a bank, its key long-term objectives and develop the strategy for achieving those objectives and undertaking the necessary activities for the purpose of realising the plans through which the set objectives are to be achieved, represents the strategic management of that bank. When reviewing the vision of a bank, one proceeds from the current position on the financial market, analysing the negative and positive factors of a bank's business operations in relation to the competition. One of the important facts essential for strategic planning is the bank's magnitude thus far, measured by the levels of the balance of liabilities and assets, as well as the level of the bank's capital.

\section{THE PROCESS AND IMPORTANCE OF STRA- TEGIC PLANNING}

Strategic planning should be based on the anticipation of the key changes in the surrounding area, the defining of new strategies based on the exploitation of the existing strengths, the exclusion of weaknesses, the discovering of new potentials and the elimination of potential weaknesses that may occur in the future. A strategy represents a plan-based decision on the basic ways of realising the aims of business operations. A competitive advantage is the basic concept for understanding strategic decision-making. From the point of view of a bank, it is possible to achieve a competitive advantage as a result of various combinations of its operations and the manner of allocating resources among those operations (Sejfert, Egić \& Nikolić, 2015, p. 84.) The banks whose strategic planning is based on offering better financial services and products, thus being better adapted to the new structure of demand for financial ser- vices, which offer better-quality and cheaper services, which apply the information technology to a high degree and conduct an appropriate marketing campaign, will be more successful in their business operations. The point to proceed from in the strategic planning of the business operations of a bank is the analysis of the overall supply of and demand for financial services as a creation of the future changes in the structure of the financial system; in accordance with this, each financial institution projects its own development strategy. The aim of such strategies is for a bank to precisely review the appropriate directions of its potential future development, so that it could position itself on the financial market in such a way to ensure the maximising of its profit and the market value of the bank. Plans should be viewed as the results of activities in which all the available information on the current and future conditions for conducting business operations are reviewed. Through planning, a bank would actually aim to achieve a greater degree of control of future developments, thus reducing uncertainty and realising that which has been planned. When planning, what should also be considered is internal organisation, for the success of a bank's business operations greatly depends on the quality and successfulness of the employees. Plans may be categorised according to various criteria: (Vunjak, Ćurčić \& Ugrinov, 2011, p. 250.)

- the time period (short-term, medium-term and longterm plans),

- the business function that a plan pertains to (for example, a marketing plan, financial plan, human resources plan),

- the organisational aspect (plans that pertain to individual organisational units and plans that pertain to a bank in its entirety),

- a hierarchy of plans (a strategic, tactical and operative plan).

Plans that pertain to a programme and aims which are to be realised during the course of one year are shortterm ones, medium-term plans pertain to a period of two to five years, whereas plans that refer to a period of more than five years are known as long-term plans. Planning activities for each business function of a bank separately is essential, for in that way one can more simply follow the business operations of the bank and evaluate the successfulness of each sector of the bank. Such a selective manner of planning makes it possible, in case of a decline in the sphere of business results, to perceive more easily and readily in which segment the problem arose by analysing what of the established plan was actually achieved. 
In order for the business operations of a bank to unfold without any appreciable problems, it is necessary to observe the procedures and rules. By applying certain procedures, one achieves a greater degree of homogeneity in conducting business operations and fulfilling tasks; also this makes it possible to educate the employees, to achieve a better communication between various management levels and to define aims more easily. By defining the aims of organising, developing the ways of realising these aims and recognising favourable opportunities, one initiates strategic planning, which is based on the complexity of the entire business surroundings.

\section{A. Strategic analysis}

Before the actual process of planning the strategy, it is necessary to conduct research into the market itself: whether it is a stagnating or declining market segment, and to analyse the inner weaknesses and strengths, upon which the selection of strategies depends. A market with a stable structure and number of consumers, the usual needs of beneficiaries, familiar technologies, familiar competitive relations, is regarded as a stagnating market. The characteristics of a declining market are a reduction of the number and structure of the beneficiaries of services, outdated technologies and non-implementation of new ones, decrease of the number of competitors, the consequence of which is the need for reducing the costs of business operations by decreasing the number of branch offices. Strategic positioning is achieved through activities that are different from those of the competitors. There are three different sources of strategic positioning: 1. being different in relation to the products and services of the competitors, 2. positioning based on needs, 3. most or all of the needs of a special group of clients being met, 4 . the basis for positioning is acceptability to the buyers, for it is possible to carry out their segmentation (Đuričin \& Janošević, 2006, p. 208). The analysis of inner strengths and weaknesses is based on the analysis of the personnel structure of the information solutions applied and the technology used. For the purpose of conducting this kind of analysis, it is very convenient to use the SWOT analysis, which presupposes the identification of inner strengths (S) and weaknesses (W), as well as opportunities (O) and threats $(\mathrm{T})$ from the surroundings.

If more elements are presented in the SWOT matrix, the position of a bank on the market will be better reviewed and clearer. After conducting this kind of analysis, one may be familiar with the economic, political and social factors from the surroundings of the bank in question, and also with its potential in terms of the personnel structure, finances and the process of business operations.

\section{VISION AND MISSION AS ELEMENTS OF STRATEGIC PLANNING}

It is of great importance to know from the outset why a business operations subject is established, that is to say, what its contribution to its surroundings is. That may be presented through a bank's mission. The mission should provide insight into the purpose of the bank, that is, into why it should exist (Stojanov \& Ugrinov, 2011, p. 252.) It is essential for banks to determine to whom they will supply their products and services and in what way, on which market or markets they will conduct their business activities, which values they will cultivate and observe. It is necessary to define a bank's vision, to review the surroundings within which it operates, its internal potential to realise that which has been envisioned, in order to be able to present its business operations. The vision and mission are oriented towards a bank's future and to what it should become. Through its vision and mission, a bank can point out to its business collaborators and potential clients what the general aims of its business operations are, and also what can be expected of it in the future. A bank's mission represents the essence of and the reason for its business operations. The five basic elements for understanding a bank's mission are: the history of the bank, the current characteristics of the management and the owner(s), the influence of the opinion of the surroundings where the bank operates, the bank's resources, the mission develops on the basis of its own ability. In order to present more precisely the direction in which the banks business operations will unfold, it is necessary to define its aims. Each aim should point to what is to be achieved and the outcome that can be expected. In order to be able to measure the results of a bank's business operations, it is desirable to express its aims quantitatively, which greatly facilitates implementing the process of control. The positive and negative factors pertaining to a bank's business operations, in relation to its competitor institutions, are as follows: 
Table 1. The positive and negative factors pertaining to a bank's business operations

\section{Positive factors}

Negative factors

\begin{abstract}
A broad client base
A developed organisational network
\end{abstract}

A good personnel structure
Poor management
Low profitability
Bad loans

A bank should review its positive and negative characteristics, in the sense of its competitive ability on the market, as precisely as possible. Of equal importance for strategic planning is the magnitude of the bank so far, measured by the level of its assets and liabilities, and also by the level of the bank's capital. Bearing all this in mind, the bank management should select a strategy of its future development that it considers to be optimal in the existing conditions. When it comes to the further development of the bank, what is important in terms of its choices is:

- whether it wishes to broaden the geographic sphere of its operations,

- which degree of diversification of its financial products it wishes to offer,

- to what extent it wishes to increase its balance level.

On the basis of thus defined choices, a bank derives implications concerning investments in the information technology, personnel structure of the network for selling financial services. Also, the aims should be arranged in a certain hierarchy in order to know which are the priority ones in relation to the time of execution and the importance of the effects to be achieved (Stojanov \& Ugrinov, 2011, p. 260). It is also desirable to group the aims in accordance with the degree of their feasibility, for in a situation when it is estimated that one aim has a high degree of priority in relation to the others, it is possible for various hindrances to occur on the path towards its realisation, which in any case aggravates the position of the bank in the process of realisation of its aims, and it also depends on the employees' motivation to go on performing their work assignments in a quality manner. When making key decisions, the bank management bears in mind the changes of the overall structure of the financial market and the bank's business strategy this far. One of the initial visions in the further operation of the bank consists in whether the bank wishes to be more oriented to the economy or to the population, whether the bank wishes to develop in the direction of a universal bank with a large number of banking products and services. Thus some banks should decide whether they wish to deal with traditional business operations or to change their orientation and become commercial-investment banks. The geographic localisation of a bank's operation depends on the bank's magnitude, for banks with a strong financial potential may cover other countries apart from their own in their business operations. The standardisation of the management system has become an issue of prime importance when it comes to the business operations of organisations on the global market in the 21 st century. By entering the international business surroundings, a bank comes into contact with numerous challenges, such as uncertainly on account of entering new and unfamiliar markets, getting acquainted with other legal regulations, the influence of new cultures (Slavić, Berber \& Leković, 2014, pp. 45-58). Apart from owners whose priority are making a profit and increasing the profit rate on the capital invested as soon as possible, various stakeholders: clients, the social community, the employees, exert increasing pressure in an organised way and demand that organisations should adapt their management system according to various standards in order to be sure in advance that their expectations will be fulfilled (Heleta, 2010, p. 164).

\section{SRATEGIC BANK MANEGMENT}

The better the management functions, the more improved is the process of exploiting all the components at a bank's disposal. There exist experiences that confirm that total integrated system management is more productive by far than individual standardised systems. By improving communications between various organisational wholes, applying information technologies, better cooperation, working in processes and not only in functions, conditions have been created for employees to strive for a total management system (Heleta, 2010, p. 209). Business resources are what the bank management has at its disposal, and what it wants to do is to achieve the bank's organisational aims. 
What is to be achieved through the circulation of banking products are the organisational aims of a bank, and these are: creating an image, reducing expenditures and increasing profit, defining the standards of quality of banking services and products, fulfilling the needs of the bank's clients. What is common to all banks is that managers at all levels possess knowledge of the result that the banks should achieve in the process of realisation. A successful management makes decisions and knows how to realise them. When it comes to how to run banks successfully, the basic element is knowledge of the banking operations and technology, which enables decisions to be implemented as well as possible. When searching for employees who can be good managers, companies look for individuals who possess technical skills, interpersonal skills, conceptual skills and management motivation (Gruber, 2001, p. 102). The features that dominate on the list of qualities are social and emotional quality: adaptability and confronting omissions and barriers, self-management, self-confidence, motivation for work and achieving aims, efficiency, team work, negotiating, leadership potential and skills (Nikić \& Travica, 2014, p. 282). Bank management should pass through the processes of planning, organising, managing, control, logistics and controlling in order to precisely define the business policy of the bank; in order to achieve this, it is necessary first of all to gather all the information on the bank's previous business operations.

Table 2. Processes of bank's previous business operations

\begin{tabular}{ll}
\hline Planning & $\begin{array}{l}\text { Encompasses the bank's activities, establishing the strategies and developing plans } \\
\text { for coordinating the bank's activities. }\end{array}$ \\
\hline Organising & $\begin{array}{l}\text { Encompasses defining the tasks to be fulfilled, the manner of their realisation, those } \\
\text { entrusted with the tasks. }\end{array}$ \\
\hline Managing & $\begin{array}{l}\text { Encompasses motivating the bank employees during the course of performing their } \\
\text { tasks. }\end{array}$ \\
\hline Control & $\begin{array}{l}\text { Encompasses overseeing the existing results, comparing them with standard values } \\
\text { and undertaking measures if need be. }\end{array}$ \\
\hline Logistics & Reducing the expenditures and time in the process of realising the bank's set aims. \\
\hline Monitoring & $\begin{array}{l}\text { Encompasses the information function and coordination, and possessing information } \\
\text { relevant for the management function. }\end{array}$ \\
\hline
\end{tabular}

Managing the business system of a bank is based on three basic inter-related systems: 1 . the management system, 2. the operative system, 3 . the information system.

The management system of a bank presupposes elements and processes of planning business activities, organising and performing tasks, as well as control of the successfulness of the results achieved. The operative system of a bank pertains to professional, quantitative and qualitative performing of tasks whose aim is to generate expenditures and income for the purpose of making a profit. The information system should fulfil the need for accurate information and support to the management and operative system of the bank.

\section{PLANINNG HUMAN RESOURCES}

In order for banks to realise their aims, it is not enough to rely on external factors only, it is necessary to stimulate all the employees to work as a team and to contribute, through their engagement, to improving the bank's business operations and to its best possible presenta- tion on the market. In order to reduce the possibility of avoiding the performance of certain tasks or shifting the blame to others in the case of inadequately performed tasks, it is necessary to precisely determine the responsibilities of individuals. When it comes to the strategy of planning human resources, there arise questions of the structure of the workforce on the basis of the level of education, of the number of workers, of the manner of obtaining additional training and education, and also of the level of personal income. By establishing the standards of job execution related to the realisation of banking services and products through the evaluation of real achievements and then controlling it, the management includes comparing the standards of operation and the actual achievements for the purpose of determining to what extent corrective measures should be undertaken. That is why it is of great importance for a manager to know the basic components of the tasks performed by his/her employees, to know the standards of work achievements and to be able to review the extent to which the employees implement the standards. 
One of the most important characteristics required in the workplace today is the ability to adapt, both under the conditions of the work process and to the people who are a part of that work process (Nikić \& Travica, 2014, p. 282).

A very important role of a manager is to be able to estimate in what way he/she should communicate with the employees so that they should be motivated for work as much as possible. Communication between a manager and the employees should ensure an entirely new working climate, the objective being to start improving the business performances with the participation of all the people in the organisation. In doing so, the employees may be enabled and motivated to learn from others with a view to complementing their own knowledge and experiences. Three key influences on the principle of leadership and participation have been established: a new awareness based on a better mutual understanding between the manager and the employees, competence that is achieved through changes for the better and involvement of the employees is the solving of problems, decision-making and proposing improvements and innovations (Heleta, 2010, p. 209). Employees differ to a great degree on the basis of how much effort they put in during the performance of everyday activities; the greatest amount of effort is required for working with clients, acquiring new knowledge and accepting new kinds of tasks. In segments of additional engagement of the employees, managers have the opportunity to stimulate the employees in various ways. In banks, the employees represent one of the most important resources, for whether their number is to increase or diminish depends on their attitude towards the clients, which is the basic factor of a bank's survival on a competitive market. The only correct management policy is a fair and equitable treatment of the employees. Getting acquainted with what a manager should not do is just as useful as getting acquainted with what he/she should do. The first and major mistake is insensitivity to others, the second mistake pertains to indifference or arrogance, the third mistake pertains to betrayal of trust, while the fourth mistake would be excessive ambition (Williams, 2010, p. 18). A manager must step out in order to understand the employees, and also for them to understand him/ her; he/she must first of all professionally perform banking tasks, respect the bank's clients, accept his/her duties and responsibilities and place the bank's interest above anything else. Management becomes an element of successful business operations through knowledge. The most successful organisations will be those that learn faster than their competition. The development of an organisation based on knowledge depends on the managers' choices. That is why it is necessary: to transform managers from users of information to creators of information, to assign to information the function of active knowledge, to eliminate excessive information and to make it possible for a manager to effectively and efficiently single out the necessary information (Heleta, 2010, p. 408-409).

Table 3. Elements and processes often encountered by managers and employees

\section{Managers}

\begin{tabular}{ll}
\hline Decision-making & Learning how to learn \\
Encouragement & Methods, techniques, tools \\
Adaptation & Diagnoses \\
Self-evaluation & Problem solving \\
Role model - by personal example & Measuring and decision-making \\
Vision & Hope \\
Team building & Trust \\
Empowerment & Self-evaluation \\
Inter-functional management & The relation buyer- supplier \\
\hline
\end{tabular}

Employers have a growing need for increasing quality of the work of employees under the modern conditions of conducting business operations and increase of stress on a daily basis, which equally affects all the actors, and emotional intelligence in the workplace has become more important than ever before (Nikić \& Travica, 2014, p. 283). Managers, as persons of authority, are considered responsible for all business-related moves. Accepting the managerial function at the same time means accepting the responsibility that goes along with it. Managers are evaluated depending on how successfully they perform the tasks entrusted to them; some of those tasks they perform with the help of the employees, and some of them they perform on their own. 
B. Management in crisis and emergency situations An efficient bank management successfully overcomes crisis situations by developing the adequacy of its strategies; by putting all defence mechanisms on alert, it is possible to deal successfully with crises and potential emergency situations. The manner of managing a business operation crisis and the budget accompanying this management belong to the planned components and the official business policy of the management. Within the framework of the business policy, the management should pay sufficient attention to a potential crisis event, and in connection with that, should establish a system of monitoring the surroundings with a view to reacting to the first signs of a crisis. For the purpose of functioning in a system of business operations affected by a crisis, the employees in all the segments of the work process in a bank should be prepared through appropriate training. A crisis situation, if managed in an appropriate manner, may prove useful through the implementation of a new strategy.

Within the business ambience of a bank, emergency situations occur frequently, so that the management must have them as part of its work description, as a potential situation of a business challenge. An emergency situation may arise both due to external and internal factors.

\section{CONCLUSIONS}

The surroundings of banks and the trends within them change continually, and these trends continue at an ever more dynamic tempo; under such conditions, planning becomes the basis of survival, which tends to change the roles of managers. Through planning, one considers various external and internal factors that may influence the performance of business-related tasks, in order to eliminate unnecessary actions and thereby make business operations more effective and efficient. A bank's vision and mission may indicate to business collaborators and potential clients what the general aims of its business operations are, and also what may be expected of it in the future. Strategic planning and the role of managers enable banks to present all the important segments of their business operations in one place, which provides a basis for following the role of a bank in the future. The basic task of a management in the banking sector is to ensure the right products and services, to realise the sale of these products and services, and that there is a tendency of their continual improvement. Banks have similar or the same aims, but the ways of realising them are different; it falls upon the management to ensure a competitive advantage as a result of various combinations of its tasks and the manner of using the resources within the bank. The management should activate the potential of the employees as a source of the acquisition of knowledge and make it possible for them to become more engaged. In order to understand others, a manager should step out; first of all, he/she must professionally perform banking tasks, accept his/her duties and responsibilities, and place the interest of the bank above everything else.

\section{REFERENCES}

Gruber, E. (2001). Cutting Time, Modern Machine Shop, 102. Đuričin, D., \& Janošević, S. (2006). Menadžment i strategija. Ekonomski fakultet, Beograd, 208.

Heleta, M. (2010). TQM Modeli izvrsnosti i integrisani menadžment system i, Zavod za udžbenike, Beograd, 164, 209, 408-409

Nikić, G., Travica, V., \& Mitrović, M. (2014). Diferences between employees and managers regarding socio-emotional competences, Serbian Journal of Managment 9(2), 282- 283.

Sejfert, Z., Egić, B., \& Nikolić, M. (2005). Strategijski menadžment, Tehnički fakultet Mihajlo Pupin, Zrenjanin, 84.

Slavić, A., Berber, N., Leković, B. (2014). Performance managment in international human resource management: evidence from the CEE region, Serbian Journal of Managment, 9(1), 45-58.

Stojanov, A., \& Ugrinov, D. (2011). Strategijski menadžment u bankarskom sistemu, Pravno - ekonomski pogledi, 252260.

Williams, C. (2010). Principi menadžmenta, Data status, Beograd, 18.

Vunjak, N., Ćurčić, U., \& Kovačević L., (2011). Strategijski menadžment u bankarstvu, Prometej, Bečej, 250. 